\title{
Model Indicators and Evaluation Criteria of Strength Readiness of Highly Qualified Arm-Wrestlers
}

\section{Oleg Kamayev ${ }^{1}$, Dmytro Bezkorovainyi ${ }^{2}$, Vyacheslav Mulik ${ }^{1}$, Igor Mazurenko ${ }^{1}$, Volodymir Gradusov ${ }^{1}$, Iryna Zvyagintseva ${ }^{2}$, Leonid Plotnytskyi ${ }^{3}$}

\author{
${ }^{1}$ Kharkiv State Academy of Physical Culture \\ 99 Klochkivska Street, Kharkiv, Ukraine, 61057 \\ 20. M. Beketov National University of Urban Economy in Kharkiv \\ 17 Marshal Bazhanov Street, Kharkiv, Ukraine, 61002 \\ ${ }^{3}$ Kharkiv National University of Civil Engineering and Architecture \\ 40 Sumska Street, Kharkiv, Ukraine, 61002
}

DOI: $10.22178 /$ pos.68-1

LCC Subject Category:

GV711

Received 19.02.2021

Accepted 28.03.2021

Published online 31.03.2021

Corresponding Author:

Dmytro Bezkorovainyi

bezkor@ua.fm

(C) 2021 The Authors. This article is licensed under a Creative Commons

Attribution 4.0 License (ब) (1)
Abstract. In the arm-wrestling technique, the main element is the attack phase, which aims to achieve a quick superiority over the enemy. Researchers Zhivora and Usanov classified four main attack methods: top attack, hook attack, push attack, and side attack. During a side attack, a great deal of stress is placed on the flexors of the hand. In connection with this, four strength exercises were selected as test indicators: flexion of the fingers, stretch with a hammer, hook and bending of the hand. These exercises were chosen to determine the level of strength readiness of highly qualified armwrestlers. The work aimed to determine the model indicators of strength readiness of highly qualified arm-wrestlers of different weight categories. The study involved $24 \mathrm{arm}$ wrestlers, 8 in the weight category up to $80 \mathrm{~kg}, 8-$ from 80 to $100 \mathrm{~kg}$ and 8 - over 100 $\mathrm{kg}$. Three test athletes are world champions in arm-wrestling, 7 are winners of European and world championships, 9 are participants in European and world championships, 5 are winners of national championships of Ukraine. The following research methods were used in work: theoretical analysis and generalization of scientific, methodological and notable information, pedagogical observation, pedagogical experiment, methods of mathematical statistics. The analysis of the strength capabilities of highly qualified arm-wrestlers and their strength readiness models made it possible to develop assessment criteria for the level of strength readiness of highly qualified arm-wrestlers of three weight categories. Three levels of strength readiness have been identified: low ( $\bar{x}$ $-\sigma)$, high $(\overline{\mathrm{x}}+\sigma)$ and medium - more $(\overline{\mathrm{x}}-\sigma)$, but less $(\overline{\mathrm{x}}+\sigma)$.

The conducted research allowed to establish the peculiarities of the levels of strength readiness development among highly qualified arm-wrestlers by weight categories. Model indicators of strength readiness of highly qualified arm-wrestlers were also determined. The analysis made it possible to state that athletes of lightweight categories (up to $80 \mathrm{~kg}$ and $80-100 \mathrm{~kg}$ ) are more harmoniously developed according to the test results. Heavy arm-wrestlers (over $100 \mathrm{~kg}$ ) showed worse results than expected.

Keywords: arm-wrestling; model characteristics; weight categories; power indicators.

\section{INTRODUCTION}

According to the analysis of competitive exercises' fulfilment, arm-sport belongs to the sports group of a speed-strength nature. The structure of competitive movements and the value of overcoming the opponent's resistance indicates the need for full dynamic manifestation and in- creased resistance from the opponent, static efforts $[1,8]$.

The nature of dynamic efforts when overcoming resistances can be different: explosive, fast, slow. Explosive strength is characterized by overcoming resistances that do not reach the limit values with maximum acceleration. 
The fast nature of efforts, or fast force, manifests itself during overcoming resistances that do not reach their limit values with acceleration below the maximum. The slow nature of efforts, or slow force, manifests itself during overcoming boundary resistances at a constant speed [9].

It is essential to distinguish that explosive strength is manifested only with overcoming muscle work. Rapid strength is manifested in both overcoming and yielding movements, also during their combination. Quiet strength is manifested during overcoming or yielding muscle work [10]. During slow force manifestation, the limiting stresses' duration is more excellent than during explosive force manifestation.

Sports and special studies' practice indicates no direct connection between developing certain dynamic and static strength types. [5]. Research results have shown that high static force does not allow for its rapid manifestation [12]. Comparing individual indices of manifestation of static and dynamic strength indicates no direct connection between developing certain muscle strength types in athletes. Thus, from a methodological point of view, this means that the effective development of any strength in highly qualified athletes' training involves using a specialized methodology [6]. In this regard, the determination of the ability to show strength capabilities in various strength exercises allows you to control and correct the training process to develop strength effectively.

Several studies $[4,11,16]$ determine the structural orientation of special strength training, thereby determining arm-wrestlers' particular strength development structure. The study results show that the structure of exceptional strength training ensures the predominant development of specific muscle groups. Structurality also contributes to technical improvement, which helps increase the magnitude of the manifestation of strength.

It was found that highly qualified arm-wrestling athletes have a relatively equally high level of technical readiness. Therefore, the fight's result will mainly depend on strength readiness level $[13,14,16]$.

In the arm-wrestling technique, the main element is the attack phase, which aims to achieve quick superiority over the opponent. According to [22], there are three primary attacks: top attack, hook attack and push attack. A questionnaire survey of specialists and research by [4] showed that highly qualified athletes use hook attack in 55\% of cases, top roll attack in $40 \%$ and push attack in $5 \%$. It was found that when performing a hook attack, the tremendous load is applied to the flexors of the hand and forearm. Top roll attack requires excessive flexor force of the fingers and hand. During the push attack, the most excellent load falls on the elbow joint and fingers. Authors [20] classified the fourth method of attack - a side attack. During this technique, a great deal of stress falls on the flexors of the hand.

In connection with the above, four strength exercises were selected as test indicators: flexion of the fingers, stretch with a hammer, hook and bending of the hand. These exercises were chosen to determine the level of strength readiness of highly qualified arm-wrestlers.

The work aimed to determine the model indicators of strength readiness of highly qualified armwrestlers of different weight categories.

\section{MATERIALS AND METHODS}

The study involved 24 arm-wrestlers, 8 in the weight category up to $80 \mathrm{~kg}, 8$ - from 80 to 100 $\mathrm{kg}$ and 8 - over $100 \mathrm{~kg}$. Three test athletes are world champions in arm-wrestling, 7 are winners of European and world championships, 9 are participants in European and world championships, 5 are winners of national championships of Ukraine.

The following research methods were used in work: theoretical analysis and generalization of scientific, methodological and noteworthy information, pedagogical observation, pedagogical experiment, methods of mathematical statistics.

Based on the analysis of the results of the study $[14,21]$, questioning the coaches and athletes, four strength test exercises were identified that have a significant impact in wrestling on the hands: flexion of the fingers, stretch with a hammer, hook and bending of the hand. The strength of the flexors of the fingers was measured using a dynamometer DK-140 (Ukraine). Strength indices in the last three test exercises were measured in a static mode with an electric tenzodynamometer of the FBk series (Poland) with an accuracy class up to $100 \mathrm{~g}$, fixed on a specialized armwrestling table using a specially made block device - "Device ARM1". During the measurement of the arm muscles' strength, the subject stood facing the table, grabbed the instrument holders with his hand, and squeezed them with maxi- 
mum force without lifting the elbow of the working hand from the table. The distance between the device holders was easy to change and was selected individually for each athlete. A particular computer program AXIS FM made it possible to process measurement data in real-time (on-line) and previously collected data from the memory of an electric tenzodynamometer (off-line). AXIS FM is compatible with Windows 7, 10 operating systems.

Statistical analysis of the obtained data was carried out using the licensed program STATISTICA 10. Statistical Analysis calculated the following parameters: arithmetic mean $(\overline{\mathrm{x}})$, standard deviation $(\sigma)$, error of representativeness $(\mathrm{m})$ and the coefficient of variation (V). Based on the obtained digital data, three strength readiness levels were determined: low, medium and high.

\section{RESULTS AND DISCUSSION}

Comparative analysis in the studied test exercises shows that most arm-wrestlers do not accidentally use a hook attack during the competition. Because in all weight categories in this exercise, athletes demonstrate the highest strength indicators compared to the data of other strength exercises (Table 1).

Analysis of the coefficient of variation (V) indicates that the results of test exercises of all groups of athletes were homogeneous. This is confirmed by the fluctuation of the numerical reflections of the static population's variability from $2.03 \%$ to $5.84 \%$ (Table 1). Comparison of the overall final indicators of the coefficients of variability (V) allows us to note that athletes weighing from 80 to $100 \mathrm{~kg}$ are distinguished by the most remarkable homogeneity $(\Sigma \mathrm{V}=$ $28,88 \%$ ). The most significant variability characterizes the group weighing more than $100 \mathrm{~kg}$ in strength indicators $(\Sigma \mathrm{V}=34,50 \%)$.
Table 1 - Model indicators of the strength readiness of highly qualified arm-wrestlers $(n=24)$

\begin{tabular}{|c|c|c|c|c|c|}
\hline Arm & $\begin{array}{c}\text { Weight } \\
\text { category (kg) }\end{array}$ & $\begin{array}{l}\text { Strength } \\
\text { indicator } \\
\overline{\mathrm{x}}(\mathrm{kg})\end{array}$ & $\mathrm{m}$ & $\sigma$ & $\begin{array}{l}\mathrm{V} \\
(\%)\end{array}$ \\
\hline \multicolumn{6}{|c|}{ Flexion of the fingers } \\
\hline \multirow{3}{*}{ left } & $<80$ & 44,34 & 0,89 & 2,52 & 5,68 \\
\hline & \begin{tabular}{|l|}
$80-100$ \\
\end{tabular} & 54,23 & 1,10 & 3,11 & 5,74 \\
\hline & $>100$ & 50,69 & 0,93 & 2,63 & 5,19 \\
\hline \multirow{3}{*}{ right } & $<80$ & 45,55 & 0,94 & 2,66 & 5,84 \\
\hline & $80-100$ & 56,81 & 0,91 & 2,57 & 4,53 \\
\hline & $>100$ & 54,48 & 1,14 & 3,22 & 5,02 \\
\hline \multicolumn{6}{|c|}{ Stretch with a hammer } \\
\hline \multirow{3}{*}{ left } & $<80$ & 47,08 & 0,68 & 1,92 & 4,09 \\
\hline & 80-100 & 62,24 & 0,91 & 2,57 & 4,14 \\
\hline & $>100$ & 57,52 & 0,45 & 1,27 & 2,21 \\
\hline \multirow{3}{*}{ right } & $<80$ & 47,86 & 0,44 & 1,24 & 2,61 \\
\hline & $80-100$ & 64,98 & 0,92 & 2,60 & 4,01 \\
\hline & $>100$ & 60,88 & 0,81 & 2,29 & 3,76 \\
\hline \multicolumn{6}{|c|}{ Hook } \\
\hline \multirow{3}{*}{ left } & $<80$ & 59,64 & 0,82 & 2,32 & 3,89 \\
\hline & $80-100$ & 84,65 & 0,69 & 1,95 & 2,31 \\
\hline & $>100$ & 75,85 & 1,19 & 3,36 & 4,44 \\
\hline \multirow{3}{*}{ right } & $<80$ & 64,46 & 0,81 & 2,29 & 3,56 \\
\hline & 80-100 & 87,98 & 0,84 & 2,38 & 2,70 \\
\hline & $>100$ & 80,28 & 0,98 & 2,77 & 3,4 \\
\hline \multicolumn{6}{|c|}{ Bending of the hand } \\
\hline \multirow{3}{*}{ left } & $<80$ & 47,16 & 0,55 & 1,56 & 3,31 \\
\hline & $80-100$ & 69,67 & 0,50 & 1,41 & 2,03 \\
\hline & $>100$ & 60,54 & 1,04 & 2,94 & 4,86 \\
\hline \multirow{3}{*}{ right } & $<80$ & 48,74 & 0,39 & 1,10 & 2,27 \\
\hline & \begin{tabular}{|l|}
$80-100$ \\
\end{tabular} & 73,73 & 0,89 & 2,52 & 3,42 \\
\hline & $>100$ & 64,93 & 1,05 & 2,97 & 4,57 \\
\hline
\end{tabular}

So, for athletes in the weight category up to 80 $\mathrm{kg}$, the difference ranges from $25 \%$ to $40 \%$, in the weight category from 80 to $100 \mathrm{~kg}$ - from 25 to $55 \%$ and by $25-50 \%$ - in athletes weighing over $100 \mathrm{~kg}$ (Table 2).

Table 2 - Generalized indicators of strength capabilities in test exercises of highly qualified arm-wrestlers $(n=24)$

\begin{tabular}{|c|c|c|c|c|c|c|}
\hline \multirow{3}{*}{ Test exercise } & \multicolumn{6}{|c|}{ Weight category, kg } \\
\hline & \multicolumn{2}{|c|}{$<80$} & \multicolumn{2}{|c|}{$80-100$} & \multicolumn{2}{|c|}{$>100$} \\
\hline & left hand & right hand & left hand & right hand & left hand & right hand \\
\hline flexion of the fingers, $\mathrm{kg}$ & 44,34 & 45,55 & 54,23 & 56,81 & 50,69 & 54,48 \\
\hline stretch with a hammer, kg & 47,08 & 47,86 & 62,24 & 64,98 & 57,52 & 60,88 \\
\hline hook, kg & 59,64 & 64,46 & 84,65 & 87,98 & 75,85 & 80,28 \\
\hline bending of the hand, $\mathrm{kg}$ & 47,16 & 48,74 & 69,67 & 73,73 & 60,54 & 64,93 \\
\hline$\sum$ indicators of arm strength, kg & 198,22 & 206,61 & 48,74 & 283,50 & 244,60 & 260,57 \\
\hline General indicator of arm strength, $\mathrm{kg}$ & \multicolumn{2}{|c|}{404,83} & \multicolumn{2}{|c|}{554,29} & \multicolumn{2}{|c|}{505,17} \\
\hline Total indicator, V \% & \multicolumn{2}{|c|}{31,25} & \multicolumn{2}{|c|}{28,88} & \multicolumn{2}{|c|}{34,50} \\
\hline
\end{tabular}


According to comparing the strength capabilities of the left and right hands in athletes of the group over $100 \mathrm{~kg}$, an increased difference in strength indicators of the left and right hands is observed. Power capabilities of the right hand are higher by 15, $97 \mathrm{~kg}(10.91 \%)$. In other weight categories (up to $80 \mathrm{~kg}$ and $80-100 \mathrm{~kg}$ ), the difference, respectively, was $8.39 \mathrm{~kg}(4.23 \%)$ and $12.71 \mathrm{~kg}$ (4.69\%). Thus, athletes' indicators up to $80 \mathrm{~kg}$ and $80-100 \mathrm{~kg}$ are stable and homogeneous.

In athletes weighing up to $80 \mathrm{~kg}$, the immediate results of testing the left hand ranged from 44.34 $\pm 0.89 \mathrm{~kg}$ to $59.64 \pm 0.82 \mathrm{~kg}$; right - from $45.55 \pm$ $0.94 \mathrm{~kg}$ to $64.46 \pm 0.81 \mathrm{~kg}$. In the weight category from 80 to $100 \mathrm{~kg}$, the strength of the left hand ranged from $54.23 \pm 1.10 \mathrm{~kg}$ to $84.65 \pm 0.69 \mathrm{~kg}$; right - from $56.81 \pm 0.91 \mathrm{~kg}$ to $87.98 \pm 0.84 \mathrm{~kg}$. In athletes weighing over $100 \mathrm{~kg}$, the strength indices of the left hand ranged from $50.64 \pm 0.93 \mathrm{~kg}$ to $75.85 \pm 1.19 \mathrm{~kg}$; right - from $54.48 \pm 1.14 \mathrm{~kg}$ to $80.28 \pm 0.98 \mathrm{~kg}$. The data obtained indicate that athletes weighing 80-100 kg demonstrate high strength indicators compared to athletes' strength data in the heavyweight category. Thus, this group's overall indicator is better by $9.7 \%$ (554.29 $\mathrm{kg}$ versus $505.17 \mathrm{~kg}$ ) (Table 2).

The analysis of the strength capabilities of highly qualified arm-wrestlers and their strength readiness models is presented; it is possible to develop assessment criteria for the strength readiness of highly qualified arm-wrestlers of three weight categories (Table 3). Three levels of strength readiness have been identified: low $(\bar{x}-\sigma)$, high $(\overline{\mathrm{x}}+\sigma)$ and medium - more $(\overline{\mathrm{x}}-\sigma)$, but less $(\overline{\mathrm{x}}+$ $\sigma)$.

Table 3 - Evaluation criteria for the level of strength readiness of highly qualified arm-wrestlers

\begin{tabular}{|c|l|l|l|c|}
\hline Arm & $\begin{array}{c}\text { Weight } \\
\text { category, kg }\end{array}$ & $\begin{array}{c}\text { Low } \\
\text { level, kg }\end{array}$ & $\begin{array}{c}\text { Medium level, } \\
\mathrm{kg}\end{array}$ & $\begin{array}{c}\text { High } \\
\text { level, kg }\end{array}$ \\
\hline \multicolumn{5}{|c|}{ Flexion of the fingers } \\
\hline left & $<80$ & $<41,82$ & $41,82-46,86$ & $>46,86$ \\
\cline { 2 - 5 } & $80-100$ & $<51,12$ & $51,12-57,34$ & $>57,34$ \\
\cline { 2 - 6 } & $>100$ & $<48,08$ & $48,08-53,22$ & $>53,22$ \\
\hline \multirow{5}{*}{ right } & $<80$ & $<42,89$ & $42,89-47,08$ & $>47,08$ \\
\cline { 2 - 6 } & $80-100$ & $<54,24$ & $54,24-59,38$ & $>59,38$ \\
\cline { 2 - 6 } & $>100$ & $<51,26$ & $51,26-57,70$ & $>57,70$ \\
\hline \multirow{5}{*}{ left } & $<80$ & $<45,08$ & $45,08-48,92$ & $>48,92$ \\
\cline { 2 - 6 } & $80-100$ & $<59,64$ & $59,64-64,81$ & $>64,81$ \\
\cline { 2 - 6 } & $>100$ & $<56,25$ & $56,25-58,79$ & $>58,79$ \\
\hline right & $<80$ & $<46,62$ & $46,62-49,10$ & $>49,10$ \\
\hline
\end{tabular}

\begin{tabular}{|c|c|c|c|c|}
\hline Arm & $\begin{array}{c}\text { Weight } \\
\text { category, kg }\end{array}$ & $\begin{array}{c}\text { Low } \\
\text { level, kg }\end{array}$ & $\begin{array}{l}\text { Medium level, } \\
\mathrm{kg}\end{array}$ & $\begin{array}{c}\text { High } \\
\text { level, kg }\end{array}$ \\
\hline & $80-100$ & $<62,38$ & $62,38-67,58$ & $>67,58$ \\
\hline & $>100$ & $<58,59$ & $58,59-63,17$ & $>63,17$ \\
\hline \multicolumn{5}{|c|}{ Hook } \\
\hline \multirow[t]{3}{*}{ left } & $<80$ & $<57,32$ & $57,32-61,96$ & $>61,96$ \\
\hline & $80-100$ & $<82,70$ & 82,70 - 86,60 & $>86,60$ \\
\hline & $>100$ & $<72,49$ & $72,49-79,21$ & $>79,21$ \\
\hline \multirow[t]{3}{*}{ right } & $<80$ & $<62,17$ & $62,17-66,75$ & $>66,75$ \\
\hline & $80-100$ & $<85,60$ & $85,60-90,36$ & $>90,36$ \\
\hline & $>100$ & $<77,51$ & $77,51-84,05$ & $>84,05$ \\
\hline \multicolumn{5}{|c|}{ Bending of the hand } \\
\hline \multirow[t]{3}{*}{ left } & $<80$ & $<45,60$ & $45,60-48,72$ & $>48,72$ \\
\hline & $80-100$ & $<68,26$ & $68,26-71,08$ & $>71,08$ \\
\hline & $>100$ & $<57,60$ & $57,60-63,48$ & $>63,48$ \\
\hline \multirow[t]{3}{*}{ right } & $<80$ & $<47,64$ & $47,64-49,84$ & $>49,84$ \\
\hline & $80-100$ & $<71,21$ & $71,21-76,25$ & $>76,25$ \\
\hline & $>100$ & $<61,96$ & $61,96-67,90$ & $>67,90$ \\
\hline
\end{tabular}

Comparative analysis of the ratios of different levels of strength indicators allowed to establish that there are completely low or high levels of strength indicators among highly qualified armwrestlers in none of the weight categories.

But in the weight category of $80-100 \mathrm{~kg}$, one athlete in all test exercises recorded the average level of strength indicators. In athletes weighing up to $80 \mathrm{~kg}, 12$ cases out of 64 (18.8\%) of low level, 37 - medium (57.8\%) and 15 - high (23.4\%) were recorded (Table 4).

Table 4 - Ratios of strength readiness levels of highly qualified arm-wrestlers $(n=24)$

\begin{tabular}{|c|c|c|c|c|c|c|c|c|c|c|}
\hline Level & & $\begin{array}{l}\text { xion } \\
\text { the } \\
\text { gers }\end{array}$ & & $\begin{array}{l}\text { retch } \\
\text { rith a } \\
\text { mmer }\end{array}$ & Ho & & & $\begin{array}{l}\text { ding } \\
\text { the } \\
\text { nd }\end{array}$ & $\begin{array}{r}\Sigma, \\
\text { un. }\end{array}$ & $\begin{array}{l}\Sigma, \\
\%\end{array}$ \\
\hline \multicolumn{11}{|c|}{$<80$ кг } \\
\hline low & 1 & 2 & 1 & 2 & 2 & 2 & 1 & 1 & 12 & 18,8 \\
\hline medium & 6 & 5 & 5 & 4 & 3 & 4 & 5 & 5 & 37 & 57,8 \\
\hline high & 1 & 1 & 2 & 2 & 3 & 2 & 2 & 2 & 15 & 23,4 \\
\hline \multicolumn{11}{|c|}{$80-100$ кг } \\
\hline low & 2 & 1 & 1 & 2 & 1 & 1 & 1 & 1 & 10 & 15,6 \\
\hline medium & 4 & 5 & 5 & 4 & 6 & 6 & 6 & 6 & 42 & 65,6 \\
\hline high & 2 & 2 & 2 & 2 & 1 & 1 & 1 & 1 & 12 & 18,8 \\
\hline \multicolumn{11}{|c|}{$>100 \mathrm{\kappa \Gamma}$} \\
\hline low & 1 & 1 & 1 & 3 & 3 & 3 & 3 & 3 & 18 & 28,1 \\
\hline medium & 5 & 5 & 5 & 4 & 3 & 2 & 3 & 3 & 30 & 46,9 \\
\hline high & 2 & 2 & 2 & 1 & 2 & 3 & 2 & 2 & 16 & 25 \\
\hline
\end{tabular}

In the weight category of $80-100 \mathrm{~kg}$, a low level was registered in $15.6 \%(n=10)$ cases, a medium level in $65.6 \%$ of indicators $(n=42)$, and a 
high level in $18.8 \%(n=12)$. In the heavy weight category (over $100 \mathrm{~kg}) 28.1 \%(\mathrm{n}=18)$ indicators of low level, $46.9 \%(\mathrm{n}=30)$ - medium and $25 \%$ $(\mathrm{n}=16)$ - high (Table 4).

Thus, the comparison of the ratios of the levels of strength capabilities of athletes of three weight categories shows that athletes weighing from 80 to $100 \mathrm{~kg}$ have the highest indicators of strength training. These figures are achieved through an overall increase in mid-level strength indicators.

Armwrestling refers to sports in which performance directly depends on strength readiness, particularly arm strength development. It was confirmed that the main predictions of success in hand wrestling include: muscle development, physical strength, the value of conditional moments of the strength of limb segments [18]. Strength fitness in many sports is used to assess athletes' physical fitness [5, 11]. According to [21], in arm-wrestling, the strength component is of decisive importance in highly qualified athletes in competitive exercises.

Confirmed data based on ergonomic approaches by [15] that high-level arm-wrestlers have a significantly higher hand strength indicator, hand flexion, forearm muscle strength, arm pronation and supination.

Hand strength indicators are the most important in hand wrestling. All athletes are characterized by high results of hand power indices, and the higher the results of these indices, the higher the success of a competitive activity. Similar data are provided by [19]. The results of [2] also confirm that the indicators of arm muscle strength are a significant predictor of success in arm-wrestling [19].

Victory largely depends on the athlete's ability to squeeze the opponent's hand as much as possible. This technique was used by Iermakov et al. [7] to predict success in martial arts.

\section{CONCLUSIONS}

The conducted research established the peculiarities of strength readiness development levels among highly qualified arm-wrestlers by weight categories. Model indicators of strength readiness of highly qualified arm-wrestlers were also determined. The analysis made it possible to state that athletes of lightweight categories (up to $80 \mathrm{~kg}$ and $80-100 \mathrm{~kg}$ ) are more harmoniously developed according to the test results. Heavy arm-wrestlers (over $100 \mathrm{~kg}$ ) showed worse results than expected. This group of athletes has not fully realized in terms of strength capabilities. These arm-wrestlers need to improve the training methodology, considering the organism's anthropo-physiological and weight characteristics.

\section{CONFLICT OF INTEREST}

The authors declare no conflict of interest.

\section{ACKNOWLEDGEMENTS}

The authors gratefully acknowledge the cooperation of the athletes, coaches and support staff who participated in this study.

\section{REFERENCES}

1. Ahamed, N. U., Sundaraj, K., Ahmad, B., Rahman, M., Ali, M. A., \& Islam, M. A. (2013). Effects of anthropometric variables and electrode placement on the SEMG activity of the biceps brachii muscle during submaximal isometric contraction in arm wrestling. Biomedizinische Technik/Biomedical Engineering, 58(5). doi: 10.1515/bmt-2013-0005

2. Akpina, S., Zileli, R., Senyüzlü, E., \& Tunca, S. A. (2013). Anthropological and Perceptual Predictors Affecting the Ranking in Arm Wrestling Competition. International Journal of Morphology, 31(3), 832-838. doi: 10.4067/s0717-95022013000300009

3. Bezkorovainyi, D. O., Mazurenko, I. O., \& Zvyagintseva, I. M. (2019). Analiz metodiki podgotovki 13kratnogo chempiona mira po armrestlingu Analysis of the methodology for preparing the 13time world champion in arm wrestling]. Martial arts, 4(14), 15-25 (in Russian) [Бескоровайный, Д., Звягинцева, И., \& Мазуренко, И. (2019). Анализ методики подготовки 13-кратного чемпиона мира по армрестлингу. ЄӘиноборства, 4(14), 15-25]. 
4. Bezkorovainyi, D. 0. (2013). Optimization of development of force and static endurance of young men in armsport [Optymizatsiia rozvytku syly ta statychnoi vytryvalosti yunakiv v armsporti]. Kharkiv: KhNUMH im. O. M. Beketova (in Ukrainian)

[Безкоровайний, Д. О. (2013). Оптимізація розвитку сили та статичної витривалості юнаків в армспорті. Харків: ХНУМГ ім. О. М. Бекетова].

5. Burdukiewicz, A., Pietraszewska, J., Stachoń, A., \& Andrzejewska, J. (2018). Anthropometric profile of combat athletes via multivariate analysis. The Journal of Sports Medicine and Physical Fitness, 58(11). doi: 10.23736/s0022-4707.17.07999-3

6. Gibadullin, I. G., Imangulov, A. R., \& Kozhevnikov, V. S. (2014). Avtomatizirovannaya sistema planirovaniya trenirovochnogo protsessa $v$ armsporte na osnove ucheta bioenergeticheskikh tipov organizma sportsmenov [Automated system for planning of training process in armwrestling in view of bioenergetic body types of athletes]. Teoriya i praktika fizicheskoy kultury, 11, 77-80 (in Russian)

[Гибадуллин, И. Г., Имангулов, А. Р., Кожевников, В. С. (2014). Автоматизированная система планирования тренировочного процесса в армспорте на основе учета биоэнергетических типов организма спортсменов. Теория и практика физической культуры, 11, 77-80].

7. Iermakov, S. S., Podrigalo, L. V., \& Jagiełło, W. (2016). Hand-grip strength as an indicator for predicting the success in martial arts athletes. Arch Budo, 12, 179-186.

8. Ilyushina, V. A. (2008). Opredeleniye svoystv i osobennostey nervnoy sistemy armsportsmenov v podgotovitelnyy period [Definition of properties and features of nervous system sportsmen in the preparatory term]. Pedahohika, psykholohiia ta medyko-biolohichni problemy fizychnoho vykhovannia i sportu, 7, 57-59 (in Ukrainian)

[Илюшина, В. А. (2008). Определение свойств и особенностей нервной системы армспортсменов в подготовительный период. Педагогіка, психологія та медико-біологічні проблеми фбізичного виховання і спорту, 7, 57-59].

9. Kamayev, O. I., Bezkorovainyi, D. O., Mazurenko, I. O., Vlasko, S. V., \& Zvyagintseva, I. M. (2020). Theoretical and methodological foundations for the use of innovative simulators of locally directed impact during the training process of highly qualified armwrestling athletes. Journal of Physical Education and Sport, 20(6), Art 488, 3622-3628.

10. Kamaev, O. I., \& Bezkorovainyi, D. O. (2013). Influence of the experimental program of trainings in armsport on the power indexes of basic muscle groups of 16-17-years-old armwrestlers. Pedagogics, Psychology, Medical-Biological Problems of Physical Training and Sports, 17(1), 34-39.

11. Karakurt, S., \& Aggon, E. (2018). Effect of dynamic and static strength training using Thera-Band ${ }^{\circledR}$ on elite athletes muscular strength. Archives of Budo, 14, 339-344.

12. Mazurenko, I. (2019). Analiz sylovykh pokaznykiv vysokokvalifikovanykh armsportsmeniv na etapi peredzmahalnoi pidhotovky [Analysis of strength performance of highly qualified arm athletes at the stage of pre-competition training]. Slobozhanskyi Naukovo-Sportyvnyi Visnyk, 6, 44-49. doi: 10.15391/snsv.2019-6.029 (in Ukrainian)

[Мазуренко, I. (2019). Аналіз силових показників висококваліфікованих армспортсменів на етапі передзмагальної підготовки. Слобожанський Науково-Спортивний Вісник, 6, 4449. doi: 10.15391/snsv.2019-6.029].

13. Moir, G. L. (2012). Muscular strength. In T. Miller, NSCA's guide to test and assessments (pp. 147192). Champaign: Human Kinetics.

14. Nikulin, I. N., \& Filatov, M. S. (2014). Ispolzovaniye izometricheskogo rezhima raboty myshts $v$ silovoy podgotovke pauerlifterov vysokoy kvalifikatsii [The use of the isometric mode of muscle work in the strength training of highly skilled arm wrestlers]. In Olimpiyskiy sport i sport dlya vsekh (p. 95). Moscow: NUFVSU (in Russian)

[Никулин, И. Н., Филатов, М. С. (2014). Использование изометрического режима работы 
мышц в силовой подготовке пауэрлифтеров высокой квалификации. В Олимпийский спорт и спорт для всех (с. 95). Москва: НУФВСУ].

15. Podrigalo, L., Iermakov, S., Romanenko, V., Rovnaya, O., Tropin, Y., Goloha, V., \& Halashko, O. (2019). Psychophysiological features of athletes practicing different styles of martial arts - the comparative analysis. International Journal of Applied Exercise Physiology, 8(1), 84-91.

16. Podrigalo, L. V., Galashko, M. N., Iermakov, S. S., Rovnaya, O. A., \& Bulashev, A. Y. (2017). Prognostication of successfulness in arm-wrestling on the base of morphological functional indicators' analysis. Physical Education of Students, 21(1), 46. doi: 10.15561/20755279.2017.0108

17. Podrigalo, L. V., Istomin, A. G., \& Galashko, N. I. (2010). Monitoring funktsionalnogo sostoyaniya sportsmenov $v$ armsporte: medikogigiyenicheskiye i sportivno-pedagogicheskiye aspekty [Monitoring of the functional state of athletes in armwrestling: medicohygienic and sportspedagogical aspects]. Kharkov: Izdatelstvo KhNMU (in Russian)

[Подригало, Л. В., Истомин, А. Г., Галашко, Н. И. (2010). Мониторинг функционального состояния спортсменов в армспорте: медикогигиенические и спортивно-педагогические аспекты. Харьков: Издательство ХНМУ].

18. Podrihalo, O. O., Podrigalo, L. V., Bezkorovainyi, D. O., Halashko, O. I., Nikulin, I. N., Kadutskaya, L. A., \& Jagiello, M. (2020). Analysis of grip strength and somatotype features of armwrestling athletes of different skill levels. Physical Education of Students, 24(2), 120-126. doi:

10.15561/20755279.2020.0208

19. Rovnaya, O., Podrigalo, L., Iermakov, S., Yermakova, T., ... Potop, V. (2019). The Application of the Index Method to Assess the Condition of Armwrestling Athletes with Different Levels of Sports Mastery. Revista Romaneasca Pentru Educatie Multidimensionala, 242-256. doi: $10.18662 / \mathrm{rrem} / 187$

20. Usanov, E. I., \& Chugina, L. V. (2006). Armrestling - borba na rukakh [Arm wrestling - hand wrestling] (2nd ed.). Moscow: Izdatelstvo Rossiyskogo universiteta druzhby narodov (in Russian)

[Усанов, Е. И., Чугина, Л. В. (2006). Армрестлинг - борьба на руках (2-е изд.). Москва: Издательство Российского университета дружбы народов].

21. Voronkov, A. V., Nikulin, I. N., \& Sobyanin, F. I. (2014). On the improvement of the control force readiness students engaged arm sport. Physical education of students, 2, 3-7.

22. Zhivora, P. V., \& Rakhmatov, A. I. (2001). Armsport. Tekhnika. taktika. metodika obucheniya [Armsport. Technique, tactics, teaching methods]. Moscow: Academy (in Russian) [Живора, П. В., \& Рахматов, А. И. (2001). Армспорт. Техника, тактика, методика обучения. Москва: Академия]. 